\title{
Apraxia: sobre a complexa relação entre corpo e linguagem
}

\author{
Melissa Catrini ${ }^{1}$
}

Catrini M. Apraxia: sobre a complexa relação entre corpo e linguagem [tese]. São Paulo: Pontifícia Universidade Católica de São Paulo; 2011.

A questão que move este trabalho foi deflagrada por questões clínicas relacionadas ao problema das Apraxias. Nos casos em que há incontestável comprometimento neurológico, qualquer presença de distúrbio articulatório é imediatamente assumida como uma Apraxia de Fala ou Disartria. Mesmo quando o comprometimento neurológico não pode ser efetivamente confirmado pelo aparato diagnóstico médico, mas se suspeita de sua existência, o raciocínio clínico tende a seguir a mesma direção. Nessas condições, especificamente, a suspeita recai sobre Apraxia de Fala, patologia comumente definida como um distúrbio motor da fala em que se observam dificuldades articulatórias e prosódicas sem prejuízos musculares. Coloca-se, assim, a questão: o que causaria tais sintomas funcionais? Apraxias têm manifestação no corpo e "corpo" é, por tradição e direito, objeto (exclusivo) do cam- po da Fisiologia e da Patologia - justifica-se, sem dúvida, a força da discursividade desses estudos sobre o tema que, como tratei de indicar, também opera no domínio da divisão filosófica mente/corpo - melhor entendido, da relação entre razão/cognição e corpo/organismo. É na esfera do dualismo corpo-mente que se inscreve (a)praxia. Entretanto, no presente estudo, Freud comparece dissolvendo o dualismo psicofísico. Nos 'escombros' da histeria e nos 'furos' da afasia, ele viu que estrutura e funcionamento não caminham lado a lado. Daí que outra concepção de corpo deve vir a figurar nos estudos sobre as apraxias. Trata-se do corpo que é Um, aquele que nasce com o ser de linguagem, ofalasser, o corpolinguagem. Diante disso, esta tese procurou problematizar a apraxia a partir da relação entre corpo e linguagem.

Trabalho realizado no Programa de Pós-graduação em Linguística Aplicada e Estudos da Linguagem, Pontifícia Universidade Católica de São Paulo - PUC-SP - São Paulo (SP), Brasil, para obtenção do título de doutor em Linguística Aplicada e Estudos da Linguagem, sob orientação da Profa. Dra. Maria Francisca Lier-DeVitto.

Fonte de auxílio: $\mathrm{CNPq}$

(1) Departamento de Fonoaudiologia, Universidade do Centro-Oeste - UNICENTRO - Irati (PR), Brasil.

Endereço para correspondência: Melissa Catrini da Silva Chinarro. UNICENTRO - DEFONO. PR 153, Km 7, Riozinho, Irati (PR), Brasil, CEP: 84500-000. E-mail: melcatrini@ hotmail.com 